\title{
ENGYODONTIUM ALBUM FUNGAEMIA: THE FIRST REPORTED CASE
}

\author{
Danielle Patrícia Cerqueira Macêdo; Rejane Pereira Neves*; Cristina Maria de Souza-Motta; \\ Oliane M. Correia Magalhães
}

Departamento de Micologia, Centro de Ciências Biológicas, Universidade Federal de Pernambuco, Cidade Universitária, Recife, PE, Brasil

Submitted: November 23, 2006; Approved: January 18, 2007

\begin{abstract}
Opportunistic mycoses have been increasingly observed among immunocompromised patients. We describe a case in which Engyodontium album was isolated and cultured from the blood of a patient with the Acquired Immunodeficiency Syndrome. E. album grew at $37^{\circ} \mathrm{C}$ and showed proteinase activity, both indicators of pathogenicity. This is the first time that this organism has been reported as agent of fungaemia.
\end{abstract}

Key words: Engyodontium album, fungaemia, Acquired Immunodeficiency Syndrome

Opportunistic mycoses have been increasingly observed in immuno-compromised patients. Engyodontium album is an unusual pathogen but a rather common inhabitant of waste or moist material and can be isolated from substrates such as paper, jute, linen, and painted walls. Its dispersal is by dry, hygrophobic conidia and can be isolated from house air (1).

E. album used to be included in the genus Beauveria (10). Limber (7) then included it in a new genus, Tritirachium, but since 1972 a new genus Engyodontium has been created which includes two species, E. album and E. parvisporum (3). Infections involving E. album include eczema vesiculosum (4), granulomatous skin lesions, brain abscess (9) and keratitis (8). In 1990, Augustinsky et al. (1) reported the first case of endocarditis caused by E. album. In this report we describe a case of E. album fungaemia in a patient with the Acquired Immunodeficiency Syndrome (AIDS) and test fungus pathogenicity.

The patient, a 18-year-old boy with AIDS, was admitted in the Clinical Hospital at Federal University of Pernambuco, Recife, Brazsil in 2002 with severe pulmonary tuberculosis. He returned in 2005 presenting $\mathrm{CD}_{4} 25$ cells $/ \mathrm{mm}^{3}$, high fever, weight loss, chronic cough, ganglion growth and oral candidiasis.

Three venous blood samples were collected in consecutive days, aseptically by venipuncture into VACUTAINER® tubes using EDTA anticoagulant. They were processed by standard methods (direct examination and isolation in culture) for mycological diagnosis at Medical Mycology Laboratory, Federal University of Pernambuco.

Direct examination was performed without clarifying and staining clinical samples. Subcultures were prepared using Sabouraud dextrose agar plus chloranphenicol (Difco Laboratories) incubated at $30^{\circ} \mathrm{C}$ and $35^{\circ} \mathrm{C}$ in an aerobic atmosphere for 15 days. Pure cultures were transferred onto the surface of potato dextrose agar medium to taxonomic identification $(5,6)$.

Preliminary pathogenicity tests were carried out through proteinase detection using casein and gelatin as substrates (6). The isolated fungus was inoculated on the referred culture medium, incubated at room temperature and at $37^{\circ} \mathrm{C}$ in order to detect the formation of a transparent halo, and observed for 10 to 15 days. When a transparent zone occurred, the result was considered positive, regardless the diameter.

Direct examination revealed septation of hyaline hyphae. Macroscopically the colonies were floccose, white, and $24 \mathrm{~mm}$ in diameter. The reverse of the colony was colorless. Microscopic examination showed narrow vegetative hyphae which were 1 to $2 \mu \mathrm{m}$ wide, bearing fertile hyphae which were 2 to $4 \mu \mathrm{m}$ wide and apically dichotomously branched, bearing conidiogenous cells in whorls of one to three. Conidiogenous cells consisted of an elongated cylindrical structure with a well- developed rachis with denticles. Conidia were hyaline, smooth, and globose (Fig. 1). The organism was identified as E. album according to the

*Corresponding Author. Mailing address: R. José Paraíso, 135/01, Boa Viagem, Recife-PE, Brasil. 51030-390. Tel.: (81) 2126-8482 E-mail: rejadel@yahoo.com.br 


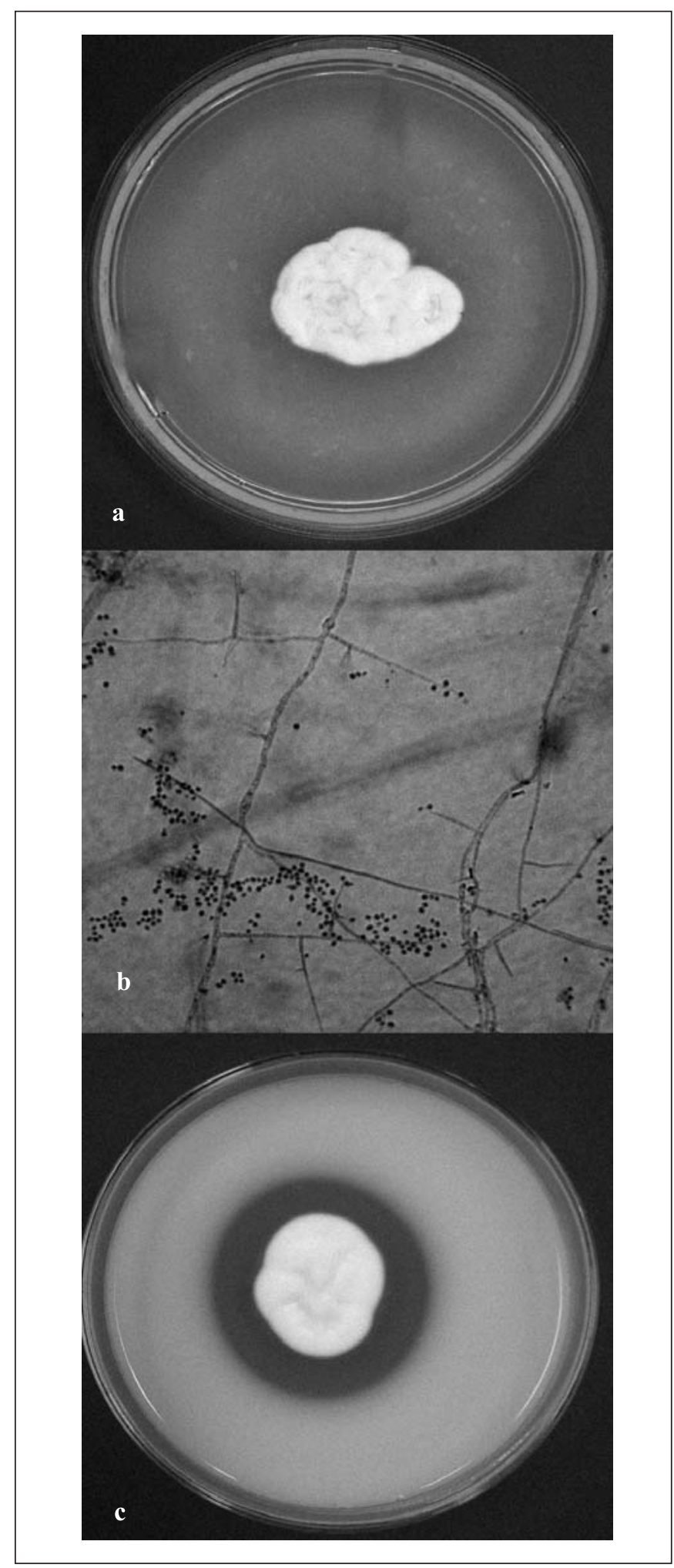

Figure 1. Characteristics of Engyodontium album: macroscopy at $37^{\circ} \mathrm{C}$ (a) microscopy (b) and proteinase activity with an evident halo formation (c). criteria described by Hoog et al. (5). This is the first case report of an AIDS patient with E. album fungaemia.

Physicians prescribed a fluconazole $(200 \mathrm{mg} /$ day $)$ therapy. After one month blood cultures were negative and the patient was discharged, although treatment was continued for six months with good results.

Pathogenicity tests indicated that the aethiological agent was able to produce proteinase in both substrates. Chellappan et al. (2) demonstrated that E. album marine isolates produce an alkaline proteinase in vitro. The involvement of E. album as the fungaemia agent and its capacity to secret extracellular enzymes has not been described yet in the literature, although there have been sporadic reports of parasitism in vivo by this hyphomycete $(1,4,8,9)$. This observation provides further evidence for the pathogenic nature of this organism.

It should be noted that Seeliger (9) did not observe E. album development at $37^{\circ} \mathrm{C}$. This may be due to a strain difference. Many fungal species that usually do not grow at $37^{\circ} \mathrm{C}$ may survive in human tissues for a considerable length of time, especially in people under immunodepressive therapy or with impaired immune defence, when introduced into or under the skin and deeper tissues $(1,9)$.

The isolate has been maintained under mineral oil (number 6066) at URM Culture Collection of Department of Mycology, Federal University of Pernambuco, Brazil.

\section{RESUMO}

\section{Fungemia por engyodontium album: primeiro caso reportado}

Micoses oportunistas têm sido progressivamente observadas entre pacientes imunocomprometidos. Nós descrevemos um caso no qual Engyodontium album foi isolado e crescido do sangue de um paciente com a Síndrome da Imunodeficiência Adquirida. E. album cresceu a $37^{\circ} \mathrm{C}$ e exibiu atividade proteásica, ambos indicadores de patogenicidade. Esta é a primeira vez que este organismo foi reportado como agente de fungemia.

Palavra-chave: Engyodontium album, fungemia, Síndrome da Imunodeficiência Adquirida

\section{REFERENCES}

1. Augustinsky, J.; Kammeyer, P.; Husain, A.; deHoog, G.S.; Libertin, C.R. (1990). Engyodontium album endocarditis. J. Clin. Microbiol., 28(6), 1479-1481.

2. Chellappan, S.; Jasmin, C.; Basheer, S.M.; Elyas, K.K.; Bhat, S.G.; Chandrasekaran, M. (2006). Production, purification and partial characterization of a novel protease from marine Engyodontium album BTMFS10 under solid state fermentation. Process Biochemistry, 41, 956-961.

3. De Hoog, G.S. (1978). Notes on some fungicolous hyphomycetes and their relatives. Persoonia, 10(1), 33-81. 
4. De Hoog, G.S. (1972). The genera Beauveria, Isaria, Tritirachium and Acrodontium gen. nov. Study Mycology, 1, 1-41.

5. Hoog, G.S.; Guarro, J. (2001). Atlas of Clinical Fungi. Centraalbureau voor Schimmelcultures/Universitat Rovira i Virgili, 1126p.

6. Lacaz, C.S.; Porto, E. (2002). Tratado de Micologia Médica. Sarvier, São Paulo, 1104p.

7. Limber; D.B. (1940). A new form genus of the Moniliaceae. Mycologia, 32: 23-30.
8. McDonnell; P.J.; Werblin, T.P.; Sigler, L.; Green, W.R. (1984). Mycotic keratitis due to Beauveria alba. Cornea, 3, 213-216.

9. Seeliger, H.P.R. (1983). Infections of man by opportunistic moldstheir identification and nomenclature of their diseases. Mykosen, 26, 587-598.

10. Vuillemim, P. (1912). Beauveria, nouveau genera de Verticillacees. Bull. Soc. Bot. Fr., 59, 34-40.

11. Weitzman, I.; Summerbell, R.C. (1995). The dermatophytes. Clin. Microbiol. Rev., 8, 240-259. 